\title{
Rapid detection of rare variants and common polymorphisms in the APC gene by PCR-SSCP for presymptomatic diagnosis and showing allele loss
}

\author{
S A Gayther, R Sud, D Wells, K Tsioupra, J D A Delhanty
}

\begin{abstract}
During the course of screening the $5^{\prime}$ half of exon 15 of the APC gene for germline and somatic mutations in two groups of patients, those with the inherited cancer prone syndrome adenomatous polyposis coli (APC) or with sporadic colorectal cancer, we have identified a number of intragenic changes that are not associated with the disease phenotype. Four of these changes are rare variants, each confined to one or two families and not detected in 50 additional unrelated people. Two common polymorphisms, at codon 1493 (exon 15I) and codon 1678 (exon 15J), were extensively investigated and found to be in almost complete linkage disequilibrium not only with each other but with a previously described polymorphism at codon 1960 (exon 15N). The rapid and sensitive single strand conformation assay used provides an efficient method for presymptomatic diagnosis using intragenic variants and was additionally used to show allele loss at the APC locus in sporadic colorectal carcinomas.
\end{abstract}

\section{(F Med Genet 1995;32:568-571)}

The inherited premalignant condition adenomatous polyposis coli (APC) is characterised by the presence of multiple benign adenomas, usually more than 100 , which develop throughout the colon and rectum of affected subjects during adolescence. ${ }^{1}$ These precancerous lesions will progress to carcinoma unless surgically removed by prophylactic colectomy. APC, a dominantly inherited syndrome, results from mutation in the recently isolated gene (APC) localised to chromosome $5 \mathrm{q} 21-22 .^{2-5}$ APC is large, consisting of approximately $8500 \mathrm{bp}$ of coding sequence and as a consequence screening of the entire gene for germline and somatic mutations has been performed by a small number of groups only. Such investigations have used a variety of mutation detection techniques which have, in general, shown deleterious germline or somatic mutations in about two thirds of affected patients and tumour material analysed. ${ }^{6}$ Thus, at present, predictive testing requires linked or intragenic polymorphisms in a large proportion of families. We have screened the $5^{\prime}$ half of exon 15 of the APC gene for mutations in a series of families segregating for the disease and, in addition to several germline mutations that have been reported, ${ }^{7}$ a number of nondisease variants were also discovered. Here we report the characterisation and frequency analysis of four rare variants and two common polymorphisms in APC detected by means of a rapid, non-radioactive single strand conformational polymorphism (SSCP) assay.

\section{Materials and methods}

The method used for analysis in this investigation was a non-radioactive SSCP assay using the Pharmacia PhastSystem ${ }^{\mathrm{TM}}$ that involves the electrophoresis of polymerase chain reaction (PCR) generated fragments in preprepared non-denaturing polyacrylamide gels followed by automated silver staining.

\section{SAMPLES}

Mutation screening was carried out in a total of 45 families with histologically confirmed APC from St Mark's and the Northern Region Polyposis Registries and the Wessex Regional Genetic Services Unit as previously described. ${ }^{7}$ Additionally paired normal and tumour tissue DNA samples from 46 sporadic colorectal cancer patients from St Mark's Hospital, London, were similarly screened for evidence of germline and somatic mutation in APC. To determine the frequency of variant alleles, lymphocyte DNA samples from random normal people and spouses from polyposis families were also tested.

\section{POLYMERASE CHAIN REACTION AMPLIFICATION} PCR amplification was performed using a Hybaid DNA thermal cycler with oligonucleotide sequences specific for exon 15, amplicons A to J, of the APC gene as described by Groden et al. ${ }^{5}$ Each reaction contained $0.2 \mathrm{mmol} / 1 \mathrm{dNTPs}$, one unit Taq polymerase (HT Biotechnology), $50 \mathrm{pmol}$ of each primer, $50 \mathrm{mmol} / 1 \mathrm{Tris}-\mathrm{HCl}, \mathrm{pH} 9.0,50 \mathrm{mmol} / 1 \mathrm{KCl}$, $7 \mathrm{mmol} / 1 \quad \mathrm{MgCl}_{2} 16 \mathrm{mmol} / 1\left(\mathrm{NH}_{4}\right) 2 \mathrm{SO}_{4}$ in a $100 \mu \mathrm{l}$ volume. Following initial denaturation at $94^{\circ} \mathrm{C}$ for four minutes, amplification involved 35 cycles of $94^{\circ} \mathrm{C}$ for 30 seconds, $48-62^{\circ} \mathrm{C}$ for 45 seconds, and $72^{\circ} \mathrm{C}$ for 45 seconds followed by a final elongation step at $72^{\circ} \mathrm{C}$ for 10 minutes. A total of $10 \mu \mathrm{l}$ of 
Table 1 Rare variants detected in the $5^{\prime}$ half of APC exon 15

\begin{tabular}{|c|c|c|c|c|c|}
\hline APC family & Amplicon & Codon/nucleotide & Sequence change & Amino acid change & Allele frequency* \\
\hline 391 & C & $\begin{array}{r}870 \\
2610\end{array}$ & $\begin{array}{l}\text { CCA } \\
\text { to } \\
\text { ICA }\end{array}$ & $\begin{array}{l}\text { Proline } \\
\text { to } \\
\text { Serine }\end{array}$ & $<0.01$ \\
\hline 552 & E & $\begin{array}{l}1083 / \\
3249\end{array}$ & $\begin{array}{l}\text { GAT } \\
\text { to } \\
\text { GAG }\end{array}$ & $\begin{array}{l}\text { Aspartic acid } \\
\text { to } \\
\text { Glutamine }\end{array}$ & $<0.01$ \\
\hline 564 II & $\mathbf{E}$ & $\begin{array}{l}1129 / \\
3386\end{array}$ & $\begin{array}{l}\text { TIG } \\
\text { to } \\
\text { TCG }\end{array}$ & $\begin{array}{l}\text { Leucine } \\
\text { to } \\
\text { Serine }\end{array}$ & $<0.01$ \\
\hline $\begin{array}{l}564 \text { I, III, and IV } \\
5998\end{array}$ & G & $\begin{array}{l}1317 / \\
3949\end{array}$ & $\begin{array}{l}\text { GAA } \\
\text { to } \\
\text { EAA }\end{array}$ & $\begin{array}{l}\text { Glutamine } \\
\text { to } \\
\text { Glycine }\end{array}$ & 0.0125 \\
\hline
\end{tabular}

* A minimum of 100 chromosomes tested.

amplification product was analysed on $2 \%$ agarose (Sigma) gels before SSCP analysis to estimate DNA concentration.

\section{SSCP ANALYSIS}

Aliquots $(1 \mu \mathrm{l})$ of the PCR generated DNA product were mixed with an equal volume of $95 \%$ formamide and reduced to a single strand state by heating at $99^{\circ} \mathrm{C}$ for 10 minutes followed by snap cooling on ice. SSCP analysis was an automated procedure performed on the PhastSystem $^{\mathrm{TM}}$ (Pharmacia, LKB) using appropriate media supplied by the manufacturers. Single stranded DNA fragments were then separated on Homogenous 20 PhastGels with PhastGel native buffer strips. PhastGels were pre-run at $400 \mathrm{~V}, 20 \mathrm{~mA}, 2 \mathrm{~W}$, and at $4-15^{\circ} \mathrm{C}$ for 10 volt hours (Vh) and electrophoresis performed at $400 \mathrm{~V}, 20 \mathrm{~mA}, 2 \mathrm{~W}$, and $4-15^{\circ} \mathrm{C}$ for $300 \mathrm{Vh}$. Gels were silver stained, again an automated procedure using the PhastSystem ${ }^{\mathrm{TM}}$ according to the manufacturer's instructions.

\section{DNA SEQUENCING}

DNA templates for sequencing were prepared by excising the PCR product previously electrophoresed through $2 \%$ Nusieve agarose gels and followed by purification with Wizard ${ }^{\mathrm{TM}}$

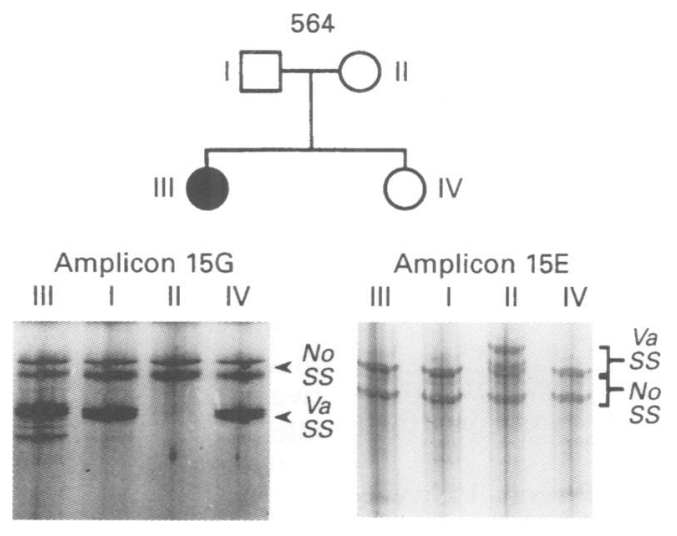

Figure 1 SSCP analysis of amplicons $E$ and $G$ of exon 15 of the APC gene in four members of family 564. Three subjects (I, III, and IV) show electrophoretic variants in the single strand DNA pattern on analysis of amplicon $G$, the single strand DNA pattern on analysis of amplicon
characterised as a single base pair substitution at codon 1317 of APC. Subject III shows additional SSCP variation which results from a new mutation (a 1 bp insertion at codon 1323) and which is predicted to truncate APC. Analysis of amplicon $E$ of exon 15 in the same four subjects shows that one (II) exhibits a SSCP variant characterised as a base pair substitution at codon 1129.
PCR purification preps (Promega) according to the manufacturer's instructions. Direct sequencing was performed by the chain termination method ${ }^{8}$ modified with the use of thermostable DNA polymerase for cycle sequencing using the Circum Vent ${ }^{\mathrm{TM}}$ cycle sequencing kit (NEB).

\section{Results}

RARE VARIANTS SEGREGATING IN APC FAMILIES As table 1 illustrates, four rare single base pair substitutions, all resulting in a change of the predicted amino acid, were characterised from the series of APC families. None of these alterations was associated with the disease phenotype.

\section{FAMILY 564}

Analysis of four members of family 564 which included one affected subject (III) resulting from fresh mutation, showed two non-disease variants by SSCP analysis (fig 1). The first was detected in amplicon 15G of APC in the affected subject and her sister (IV) and had been inherited from their father (I). Sequence analysis of DNA from all three subjects with the variant SSCP pattern showed the alteration to be the result of a previously reported $G$ to $C$ substitution at codon 1317 causing an amino acid change from glutamine to glycine (table 1). ${ }^{9}$ An identical alteration was also observed in two unaffected people from another APC family (5998) in which the germline mutation has been characterised as a $5 \mathrm{bp}$ deletion occurring at codon 1309 of the APC gene. ${ }^{7}$

The second variant was detected in amplicon $E$ of exon 15 and was observed in the affected subject's mother (II) only. Sequence analysis characterised this alteration as a $T$ to $C$ substitution at codon 1129 resulting in a predicted amino acid change from leucine to serine. This rare non-disease variant has also been detected in an APC kindred by Allan et al. ${ }^{9}$

The affected member of family 564 exhibits an additional SSCP variant in amplicon $15 \mathrm{G}$ of the gene which is the result of a single base pair insertion at codon 1323; this is the disease causing mutation. ${ }^{7}$

\section{FAMILY 552}

An SSCP variant was also observed in amplicon $15 \mathrm{E}$ of the APC gene in both affected and unaffected members of family 552 . Subsequent 

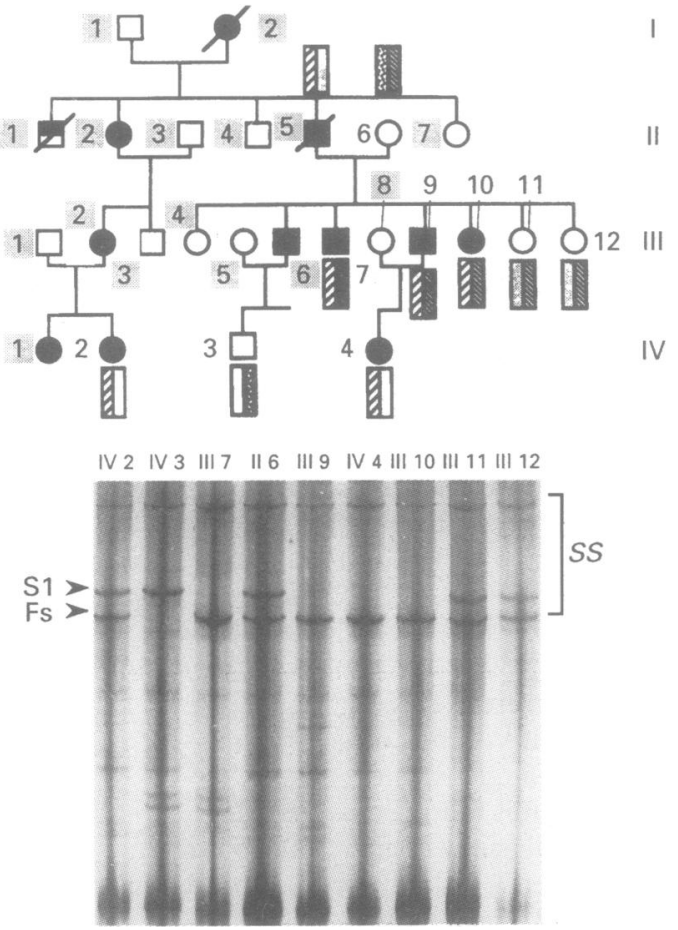

Figure 2 Characterisation of nine subjects in three generations from a large APC pedigree for the frequent polymorphism at 1493 of APC detected in amplicon I of exon 15. Previously derived haplotypes segregating within the family, including the disease associated haplotype, are also illustrated.

sequence analysis showed this SSCP variant to be the result of a $T$ to $G$ substitution at codon 1083 creating a glutamine recognition codon from aspartic acid. That this change was observed in unaffected people indicated that it was likely not to be the disease causing mutation in this family and it was subsequently shown to segregate with the unaffected haplotype. However, as the disease causing mutation in this family has not been found, the variant described here allowed the gene status of a person at $50 \%$ risk of inheriting the disease to be determined.

\section{FAMILY 391}

In family 391, a rare variant SSCP pattern was observed to segregate with the disease. It was subsequently shown to result from a single base pair substitution of a $T$ for a $C$ at codon 870 (exon $15 \mathrm{C}$ ) causing an amino acid change from proline to serine. This variant has been reported by Powell et al. ${ }^{11}$ The disease associated mutation in this family was shown to be the common $5 \mathrm{bp}$ deletion at codon 1061 (amplicon 15E). ${ }^{7}$

Amplicons C, E, and G of exon 15 were analysed by SSCP in at least 50 unrelated

Table 2 Analysis of allele frequency for the common polymorphism at codon 1493

\begin{tabular}{|c|c|c|c|c|c|c|}
\hline \multirow{2}{*}{$\begin{array}{l}\text { Individual subset } \\
\text { (total number) }\end{array}$} & \multicolumn{2}{|c|}{$\begin{array}{l}\text { Slow allele } \\
\text { homozygous }\end{array}$} & \multicolumn{2}{|c|}{$\begin{array}{l}\text { Slowlfast allele } \\
\text { heterozygous }\end{array}$} & \multicolumn{2}{|c|}{$\begin{array}{l}\text { Fast allele } \\
\text { homozygous }\end{array}$} \\
\hline & No & $\%$ & No & $\%$ & No & $\%$ \\
\hline $\begin{array}{l}\text { Unrelated subjects }(155) \\
\text { Normal subjects }(73) \\
\text { APC patients ( } 45) \\
\text { Sporadic colorectal cancer cases (46) }\end{array}$ & $\begin{array}{l}51 \\
23 \\
16 \\
16\end{array}$ & $\begin{array}{l}32 \cdot 9 \\
31 \cdot 5 \\
35 \cdot 6 \\
34 \cdot 8\end{array}$ & $\begin{array}{l}79 \\
39 \\
19 \\
25\end{array}$ & $\begin{array}{l}51 \cdot 0 \\
53 \cdot 4 \\
42 \cdot 2 \\
54 \cdot 3\end{array}$ & $\begin{array}{r}25 \\
11 \\
10 \\
5\end{array}$ & $\begin{array}{l}16 \cdot 1 \\
15 \cdot 1 \\
22 \cdot 2 \\
10 \cdot 9\end{array}$ \\
\hline
\end{tabular}

people from a variety of geographical and ethnic origins. None of the rare variants described was detected in these samples.

\section{COMMON POLYMORPHISMS}

The most frequent alteration initially observed through analysis of exon 15 of APC was detected in amplicon $\mathrm{I}$, the result of a single base pair substitution of $\mathrm{G}$ for A at codon 1493. This is a silent alteration resulting in no amino acid change. Initially SSCP analysis to detect this change was performed at $15^{\circ} \mathrm{C}$ at which temperature the variant single strand pattern differed between unrelated subjects appearing as either two poorly separated bands or one of two single bands with slightly different mobilities. Electrophoresis performed at $10^{\circ} \mathrm{C}$, however, resulted in clear separation of all single strand bands, unrelated subjects being classified as either slow migrating homozygotes, fast migrating homozygotes, or slow/fast migrating heterozygotes (fig 2).

The nature of this polymorphism was characterised in families segregating for APC, a panel of normal subjects, and a series of sporadic colorectal cancer (CR) patients with corresponding carcinoma tissue. In total, 155 unrelated people were tested (38 patients with APC, 46 sporadic CR patients, and 71 people unaffected with either disorder).

As table 2 illustrates, a little over half of all unrelated subjects $(51 \%)$ were heterozygous for the common polymorphism at codon 1493 (exon 15 I), with approximately one third $(32.9 \%)$ slow migrating homozygotes and the remainder $(16 \cdot 1 \%)$ fast migrating homozygotes. The resultant allele frequencies were 0.58 for the slow migrating allele and 0.42 for the fast migrating allele. There appears to be little variation between the allele frequencies of the three different subsets although among the group of APC patients there was an increased homozygote frequency (table 2) (for separate analysis, this subset was increased by the inclusion of seven fresh mutation cases)

Extending the region of the APC gene analysed in sporadic colorectal cancer patients showed a second frequent alteration detected as an SSCP variant and characterised as a single base pair substitution of an $A$ with a $G$ at codon 1678 (exon 15, region J) also without a resultant amino acid change. In total, DNA from 87 unrelated people was analysed for both of these polymorphisms and none was discordant, indicating complete linkage disequilibrium between them. For both polymorphisms the two alleles of heterozygotes representative of both polymorphisms were clearly distinguishable as variant conformers in the single strand DNA pattern and as such both are potentially valuable for analysis of allelic loss in colorectal tumours. Subsequently analysis of tumour and normal tissue for each of the $\mathbf{4 6}$ sporadic colorectal cancer patients showed loss of heterozygosity in eight tumours from the 25 patients $(32 \%)$ who were heterozygous for the common polymorphisms and therefore informative (fig 3). Additionally, DNA from 50 unrelated people that had been analysed for 


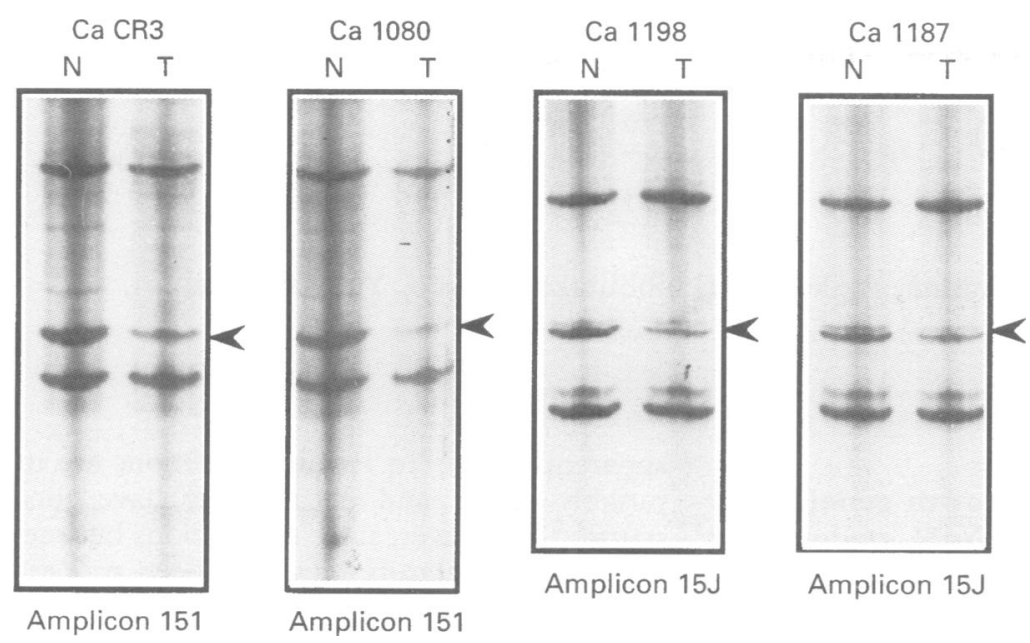

Figure 3 Allele loss detected in colorectal carcinomas with matching constitutional DNA analysis from four sporadic colorectal cancer patients. Detection of allele loss as shown (arrows) involves the analysis of two frequent polymorphisms at codons 1493 and 1678 in amplicons 151 and 157 of the APC gene respectively.

the exon $15 \mathrm{I}$ and $\mathrm{J}$ variants were also typed by PCR for the previously described MspI polymorphism, FB54D, ${ }^{12}$ that occurs in the APC exon 15 region $N$ (codon 1960). With the exception of two CR cancer patients linkage disequilibrium was complete in all samples with the slower migrating alleles corresponding.

\section{Discussion}

Despite determination of the causative mutation in a high proportion of families there remains a need to determine the gene status of subjects within APC kindreds by linkage analysis with polymorphic markers around the APC locus. Recently a highly polymorphic (CA) repeat locus adjacent to the APC gene has been reported and its potential use in presymptomatic diagnosis highlighted. ${ }^{13}$ Although potentially more informative than the intragenic polymorphisms described in the current study, analysis using such markers is difficult and time consuming and frequently involves the use of radioisotopes. As an initial determinant of gene status in at risk subjects, therefore, the non-radioactive SSCP analysis described here is ideal.

We have also shown the use of such a system for rapid and efficient characterisation of allele loss in tumours. The clarity of the results that we have obtained compares favourably with those derived from the use of dinucleotide repeat markers.

The frequent polymorphism at codon 1493 (exon 15 I) characterised in detail here has previously been reported by others. ${ }^{1114}$ The single base pair substitution itself creates a BsaJI restriction enzyme site within the APC gene and this has recently been used to determine the gene status of 20 subjects based on digestion of PCR generated fragments en- compassing the polymorphic site before agarose gel electrophoresis. ${ }^{15}$ Similarly, the codon 1678 (exon $15 \mathrm{~J}$ ) polymorphism was described earlier $^{14}$ and analysis by HgiAI digestion of PCR products has been reported. ${ }^{16}$ The SSCP analysis performed here to characterise these polymorphisms is preferable to the digestion assays in that it eliminates the intermediary digestion step which in itself presents a possible source of error (that is, incomplete or failed digestion), and is also a more rapid procedure taking approximately two and a half hours to perform. Furthermore, the SSCP analysis described does not appear to suffer from the imprecision produced by similar radioisotopic assays. From our data linkage disequilibrium between these two polymorphisms and the one at codon $1960^{12}$ appears almost complete; for routine diagnostic use it is therefore only necessary to type one of the three. The implication of this finding is that intragenic recombination within exon 15 of APC is rare.

We thank the staff of the St Mark's and Northern Region Polyposis Registries and of the Wessex Regional Genetics Services for provision of family material and the Pathology Department of St Mark's Hospital, London for the colorecta cancer samples. SAG was funded by a Medical Research Council Studentship and support for KT and RS was provided by Quest Cancer Research.

1 Bussey HJR. Familial polyposis coli. Baltimore: Johns Hopkins University Press, 1975.

2 Kinzler KW, Nilbert MC, Su LK, et al. Identification of FAP locus genes from chromosome 5q21. Science 1991; 253:661-4.

3 Joslyn G, Carlson M, Thliveris A, et al. Identification of deletion mutations and three new genes at the familial polyposis locus. Cell 1991;66:601-13.

4 Nishisho I, Nakamura Y, Miyosyi Y, et al. Mutations of chromosome $5 \mathrm{q} 21$ genes in FAP and colorectal cancer patients. Science 1991;253:665-9.

5 Groden J, Thliveris A, Samowitz W, et al. Identification and characterization of the familial adenomatous polyposis coli gene. Cell 1991;66:589-600.

6 Nagase H, Nakamura Y. Mutation of the APC (adenomatous polyposis coli) gene. Hum Mutat 1993;2:42534.

7 Gayther SA, Wells D, Sen-Gupta SB, et al. Regionally clustered APC mutations are associated with a severe phenotype and occur at a high frequency in new mutation cases of adenomatous polyposis coli. Hum Mol Genet 1994; 3:53-6.

8 Sanger F, Nicklen S, Coulson AR. DNA sequencing with chain-terminating inhibitors. Proc Natl Acad Sci USA 1977;74:5463-7.

9 Allan GJ, Cottrell S, Trowsdale J, Foulkes WD. Loss of heterozygosity on chromosome 5 in sporadic ovarian carcinoma is a late event and is not associated with mutations in APC at 5q21-22. Hum Mutat 1994;3:283-91.

10 Groden J, Gelbert L, Thliveris A, et al. Mutational analysis of patients with adenomatous polyposis: identical inactivating mutations in unrelated individuals. $\mathrm{Am} \mathcal{F} \mathrm{Hum}$ Genet 1993;52:263-72.

11 Powell SM, Zilz N, Beazer-Barclay Y, et al. APC mutations occur early during colorectal tumorigenesis. Nature 1992; 359:235-7.

12 Cottrell S, Bodmer WF. Two MspI polymorphisms within the APC gene. Hum Mol Genet 1992;1:352.

13 Spirio L, Nelson L, Ward K, et al. A CA repeat polymorphism close to the adenomatous polyposis coli (APC) gene offers improved diagnostic testing of familial APC. gene offers improved diagnostic testir

14 Nagase H, Miyoshi Y, Horii A, et al. Screening for germline mutations in familial adenomatous polyposis patients: 61 new patients and a summary of 150 unrelated patients. Hum Mutat 1992;1:467-73.

15 Davies SM, Snover DC. Frequent polymorphism in exon 15 of the adenomatous polyposis coli gene. Hum Genet 1994;93:329-30.

16 Kraus C, Ballhausen WG. Two intragenic polymorphisms of the APC gene detected by PCR and enzymatic digestion. Hum Genet 1992;88:705-6. 